\title{
THE RELATIONSHIP AMONG CUSTOMER SATISFACTION, LOYALTY AND FINANCIAL PERFORMANCE OF COMMERCIAL BANKS
}

\author{
Jaroslav Belás, Lenka Gabčová
}

\section{Introduction}

Customer satisfaction is an important factor in the performance and competitiveness of banks (Keisidou et al., 2013; Chavan \& Ahmad, 2013; Belás, Chocholáková, \& Gabčová, 2015). Compliance with the consumers' needs and requirements (Bilan, 2013), comprehensive customer care and the bank customers satisfaction is currently in the centre of attention of researchers and bankers (as it represents an important marketing variable for most of the companies (Munari et al., 2013).

According to Hernaus \& Stojanovic (2015) recent financial turmoil, uncertain and unstable world and increasing public pressure have put financial sector and its responsibilities under great scrutiny. This has led to putting more emphasis on social responsibility of financial institutions, primarily banks, due to a powerful and influential position they have. In this context Burianová \& Paulík (2014) state that the monitoring and measuring customers' satisfaction plays very important role in area of Corporate Social Responsibility in commercial banks.

Traditionally, it was supposed that satisfied customers are less prone to switch their bank and more willing to purchase additional products. However, various papers have not confirmed these relationships and, on the opposite, showed that even satisfied customers do not hesitate to switch their bank if a competitor bank offers them a better product. This fact can be explained in two ways.

The first is the term of loyalty. Loyal clients have a more intense connection to their bank, more emotionally-based, thus they are more resistant to a competitors' offer even if it was of higher quality.

The second way to explain the weak relationship between customer satisfaction and their retention is that not only objective factors (e.g. price, technical parameters of a product or distribution channels reliability) determine the customer satisfaction. Subjective feelings and experience of a customer play a key role as well.

Researchers who studied customers' satisfaction and loyalty in the banking sector have employed large variety of mathematical and statistical methods. Arguably the most frequently used methodology is a regression analysis framework (e.g., Murugiah \& Akgam, 2015; Kheng et al. 2010; Wang \& Wallendorf, 2006). Descriptive and simple inferential analysis are widely used as well (Chavan \& Ahmad, 2013; Munari et al., 2013; Bena, 2010). Association between qualitative factors in contingency tables is analysed by Pearson's statistics (Belás, Cipovová, \& Demjan, 2014). Models which contain latent constructs are often examined by Factor Analysis (Fraering \& Minor, 2013; Arbore \& Busacca, 2009 or by Structural Equation Modelling approach (e.g., Fatima \& Razzaque, 2014; Matzler et al. 2007). Preferred data acquisition way is a questionnaire survey.

Thus this study deals with the two abovementioned areas. It examines relationships between subjective factors, levels of customer's satisfaction and loyalty and estimates effects on additional product purchasing. Analysis is carried out by regression analysis tools.

\section{Theoretical Background}

\subsection{Customer Satisfaction in a Commercial Bank}

Customer satisfaction can be explained by two types of theories. Firstly, cognitive theories compare the reality with a certain standard. After purchasing and using the product, customers evaluate not only the performance of this product but also the experience they obtained during the 
process of its purchasing. Then they compare this real experience with their expectations and if it is at least as good as they expected (or better), they become satisfied (Chavan \& Ahmad, 2013; Oliver, 2010). The second group of theories is called affective and is arguing that emotions and subjective feelings are more important. Nevertheless, most authors opine that customer satisfaction is a result of a simultaneous interaction between both cognitive and affective evaluation (Bena, 2010; Clerfeuille et al., 2008). There are also authors denying the influence of the purchasing process thus stating that only parameters of the product determine customer satisfaction (Wang \& Wallendorf, 2006). On the other hand, some authors expand the model of customer satisfaction and include the distributors as well as they are in direct contact with the final consumer and provide their own services also influencing the overall customer satisfaction (Shiv \& Huber, 2000).

Essential in forming customer satisfaction are not only objective measurable parameters such as interest and fees but also subjective feelings and sensations (e.g. feeling of being appreciated in the bank, personnel attitude to the customer's needs etc.). As these are hardly measurable and unpredictable, it makes the process of managing customer satisfaction in a commercial bank very difficult. (Belás, Cipovová, \& Demjan, 2014)

Customer satisfaction in the banking sector has its specific features mostly due to the fact that it is the sector of services. Customers cannot evaluate the product beforehand, e.g. by a free sample, but only after the interaction with a certain bank. This interaction can be with the organization as such, with their business processes or their employees. Thus these three areas have to be in the centre of attention of a bank when improving customer satisfaction (Bena, 2010).

\subsection{Determinants of Customer Satisfaction}

According to Roig et al. (2009), perceived value is the antecedent of customer satisfaction. They have argued that perceived value is multidimensional and consists of six dimensions: functional value of the installations of the establishment, functional value of the customer service personnel, and functional value of the service quality, functional value price, emotional value and social value.
Lenka et al. (2009) have examined the service quality and the effect of service quality in building customer satisfaction and how customer satisfaction leads to customer loyalty.

According to Arbore \& Busacca (2009), one of the key determinants of customer satisfaction is the price, be it its height, perceived fairness or price-quality ratio. These authors also emphasize the importance of solving the possible problems and mistakes fast and efficiently. On the other hand, the localization of a branch, its accessibility and layout are supposed to have only a marginal impact.

Matzler et al. (2007) argue that the relationships between customer satisfaction and its determinants tend to be nonlinear, influence each other among themselves or can be found only in some segments. Munari et al. (2013) summarize all the explored factors to date in one concept divided into two levels. The first level is called dimensions and includes reputation, functional quality, relation quality, problem solving, pricing, comfort and layout/ equipment. Every dimension subsequently contains various attributes, e.g. the attributes of functional quality are reliability, response times, service functioning and channel functioning. Similarly, Keisidou et al. (2013) state variables like economics, tangibles, relational quality, image, value and brand have a significant positive relationship with customer satisfaction.

\subsection{Customer Satisfaction Consequences}

Many papers have confirmed that a bank with satisfied customers has a higher profitability (Chi \& Gursoy, 2009; Bernhardt et al., 2000; Arbore \& Busacca, 2009; Zeithaml, 2000). For instance, Arbore \& Busacca (2009) declare that customer satisfaction is an assumption of various patterns of customer behavior wished by a bank, such as purchasing additional products, positive Word of Mouth, willingness to pay premium prices or perceiving the bank as customer-oriented. These patterns then influence the key performance indicators of a bank (ability to retain a client, average deposit sums, service costs or future income) and after all the profit of a bank.

Bernhardt et al. (2000) points out that the relation between customer satisfaction and the profit of a bank can be less intense in a short term (up to 12 months) due to numerous factors influencing the financial performance of a bank. 
The relation is significant and easy to prove in a long term though. On the other hand, there are several studies that have not confirmed such relationship at all (Kamakura et al., 2002).

Gursoy \& Swanger (2007) found out that customer satisfaction might not improve the financial performance of a company in the service sector. It is because customer satisfaction is perceived as a given factor, meaning that customers expect the service to fulfill their expectations already during the purchasing process. Thus it can be concluded that customer satisfaction is a necessary yet not sufficient assumption of a higher financial performance of a bank.

\subsection{Customer Loyalty}

Reasons why even customer satisfaction does not guarantee customer retention are examined by numerous papers. For example, Fraering \& Minor (2013) explain this fact by the term of customer loyalty. Loyal clients have more intense connection to their bank, based more on emotions. The relationship with their bank is thus much stronger than satisfied customers have. The consequence of such connection is the customer willingness not only to purchase additional products from their bank but also to inform their friends and family about this positive relation.

Murugiah \& Akgam (2015) add that loyal clients tend to provide more information about them, based on the trust they have towards their bank. However, Cohon (2007) warns this strong connection can be counterproductive. A customer can become loyal to a certain employee and not to the whole organization. In case of losing this employee, a bank can lose the client as well. Thus building customer loyalty cannot be fully decentralized to the employees of first contact. Instead, banks have to deal with it at the top management level and define the common processes so that customers become loyal to the bank as such.

\subsection{The Relation between Customer Satisfaction and Customer Loyalty}

Lenka et al. (2009) propose that integrated human, technical and tangible aspects of services are not only associated with a higher level of customer satisfaction but also with an improved level of customer loyalty. Accordingly, Kheng et al. (2010) state reliability, assurance and empathy are the most important dimensions of service quality that can increase customer loyalty. The authors have found that improved service provided by the employees is the most significant factor of customer loyalty.

The research of Munari et al. (2013) showed a strong positive correlation between customer satisfaction and customer loyalty. Satisfaction is thus a basic prerequisite of customer retention what has been confirmed by a positive correlation between customer dissatisfaction and the intensity of their quitting. At the same time, this correlation was weaker than the previous one as clients quit not only due to their dissatisfaction but also due to other reasons, such as personal motivations (change of their employer, residence or household income) and bank's selection policy. Khan \& Fasih (2014) also confirmed the influence of customer satisfaction on customer loyalty.

According to Khan \& Rizwan (2014), customer satisfaction explains $93 \%$ of customer loyalty in the banking sector. However, there are authors declaring the relationship works vice-versa, i.e. customer satisfaction depends on customer loyalty (Murugiah \& Akgam, 2015). These authors define customer loyalty as the willingness to deal with their bank despite other banks' offers even though these offers were of comparable or higher quality.

\subsection{Consequences of Customer Loyalty}

Various studies come to the conclusion that consequences of customer loyalty are very similar to these of customer satisfaction. Khan \& Fasih (2014) and Gee et al. (2008) summarize the possible outcomes of customer loyalty as: reducing customers' quitting, boosting sales (represented by additional purchases of products and services), lower service costs comparing to new clients, positive Word of Mouth leading to acquisitions of new customers, increasing the market share and willingness of loyal customers to pay premium prices. All the above-mentioned outcomes have a positive impact on the commercial bank's profitability what was confirmed by studies of Liang et al. (2009), Smith \& Wright (2004), AlWugayan \& Pleshko (2010). Smith \& Wright (2004) explain that loyal clients are less priceelastic thus companies can afford to increase prices without a negative effect on sales. Khan \& Rizwan (2014) found that if a company reduces the customer quitting by $5 \%$, it raises its profits by $2-8 \%$. 
Nevertheless, there are some papers not confirming such relationships, e.g. Keisidou et al. (2013) argue that neither customer satisfaction nor customer loyalty is a significant predictor of bank financial performance in terms of return on assets or investment, net profit margin and return on equity.

Customer loyalty assessment is a complex decision problem, where evaluations are not easy and are strongly dependent in different stakeholders with different and often conflicting values and preferences. In this context, searching for optimal solutions was considered as an unrealistic possibility. (Ferreira et al., 2015)

To sum up, the conclusion of the up to date literature is an idea that customer satisfaction leads to customer loyalty and loyalty leads to willingness to purchase additional products. However, there are practically no papers quantifying the influence of loyalty on additional products purchases. Thus the main contribution of this article is the quantification of the influence of loyalty on additional products purchases and subsequently, the influence of additional products purchases on a commercial bank's financial performance.

\section{Objectives, Methodology and Data}

The aim of this paper is to create a model of customer satisfaction, customer loyalty and financial performance of a commercial bank, and to quantify the dependence of additional purchases of banking products from customer loyalty.

According to the findings of Arbore \& Busacca (2009), Munari et al. (2013), Fraering \& Minor (2013), Khan \& Fasih (2014), Murugiah \& Akgam (2015), Belás \& Gabčová (2014), Belás, Cipovová, \& Demjan (2014), we proposed a model that is depicted in Fig. 1.

Quantitative research on satisfaction, loyalty and additional purchases in the Czech banking sector was performed 2014. Survey was conducted on on the questionnaire survey on a sample of 459 respondents, of which $44 \%$ were men. The age structure of respondents was as follows: $39 \%$ of respondents were aged less than 30 years old, $44 \%$ of respondents were in the group 31 to 50 years and remaining $17 \%$ were customers older than 50 years. The education level of respondents was as follows: $3 \%$ had primary education, $54 \%$ had secondary education and $43 \%$ held university degree.
Non-probabilistic sampling method was used to create convenience sample. This sample was created by collecting responses from accessible respondents and their family members. Although this approach is prone to bias (sample statistics can deviate from general behaviour which is present in the population) large sample size and second-level respondents (family members) mitigate bias risk.

The final model is an aggregate of three separate sub models. The relationship between customer satisfaction and its determinants was described by multiple regression analysis; the relationship between customer satisfaction and loyalty and between customer loyalty and additional product purchases willingness was described by simple regression.

In this study, regression analysis was applied to explain the relations between single variables and not to predict these variables. As customer satisfaction and its determinants, loyalty and willingness to purchase additional products were researched, regression analysis was an appropriate technique as all the mentioned variables are metric. There was assumed that the relationships between single variables are statistical and not functional because subjective evaluation by respondents was included and thus can contain measurement errors, so called residuals. As for the over fitting, the appropriateness of the sample was ensured by a sufficient number of reached respondents. The ratio of the number of observations to the number of independent variables included in the model was $98.1: 1$ in the model of customer satisfaction and its determinants what exceeds substantially the recommended values of 15-20 observations to 1 independent variable included in the model.

\subsection{Testing Independent Variables to Meet the Assumptions of Linear Regression}

Every single one from the three sub models was tested separately. The linearity assumption was tested by scatter plots and was met if no nonlinear patterns were observed in the relationship between the dependent and independent variables. The normality assumption was tested in two ways:firstly, bycreating a normal probability plot for every independent variable; secondly, by a statistical test measuring two characteristics of every variable (kurtosis and skewness) and then 
Fig. 1: Proposed model of customer satisfaction and its determinants, customer loyalty and additional purchases potential of a customer

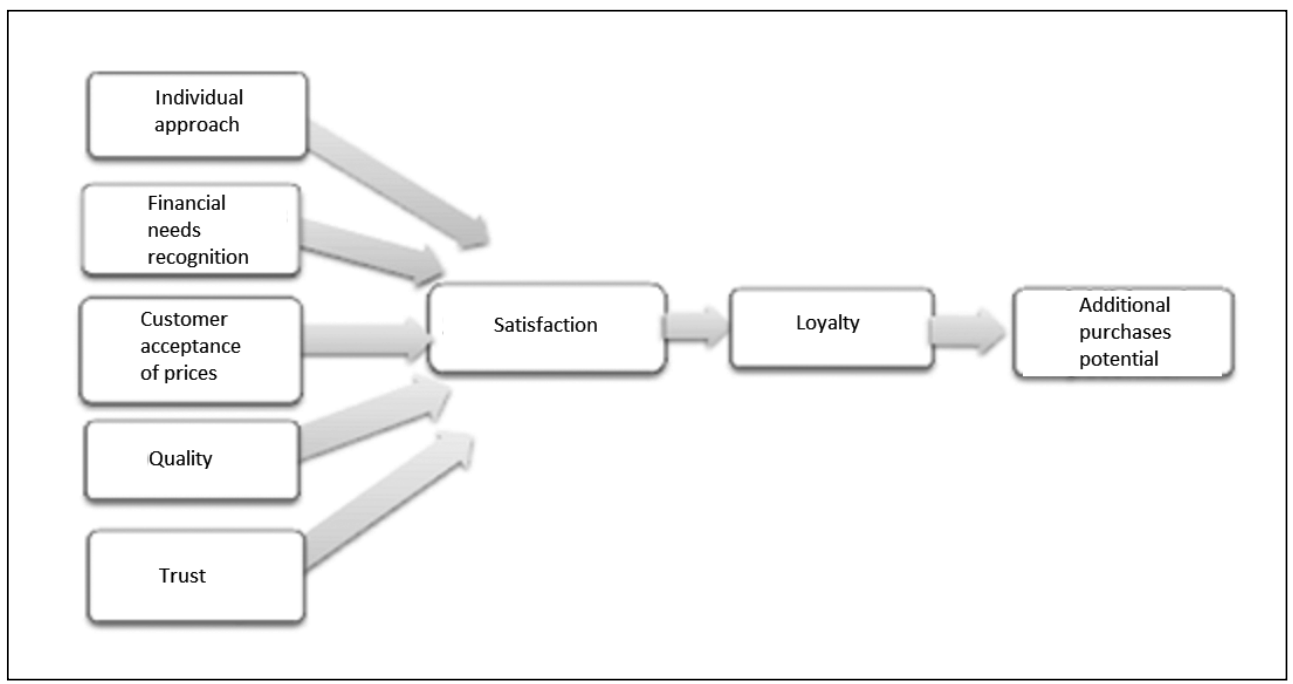

Source: own source

statistical z-value for each characteristic. These statistical tests were conducted according to Hair (2010); the critical value for the significance level of 0.05 was \pm 1.96 . Homoscedasticity was tested by a graphical test as well. Firstly, there was performed a regression analysis for every pair of independent and dependent variable. Secondly, the regression analysis output was used to create a scatter plot. The homoscedasticity assumption is met if points are distributed homogenously throughout the scatter plot. Adding a trend line provide with an extra proof of homoscedasticity. If this trend line is a parallel to $x$-axis, it points to the homoscedasticity of a tested independent variable.

\subsection{Model Estimation, Testing and Validation}

To create a sub model between customer satisfaction and its determinants there was used the stepwise method of multiple regression analysis. Independent variables were included in the model if their calculated t-value $\geq 1.9462$ (457 degrees of freedom, significance level at 0.05). Sub models of relationships between customer satisfaction and loyalty and between customer loyalty and willingness to purchase additional products were created by immediate inclusion of independent variables as in both cases there was only one independent variable to consider.

All created sub models were then tested as a whole to meet the assumptions of linear regression. Totest the linearity, homoscedasticity and independence of residuals, a standard residual plot for each dependent variable was utilizedthere. The above mentioned assumptions were met if standard residuals were distributed homogeneously throughout the plot and showed stochastic behavior.

The normality assumption was also tested graphically, using normal probability plot for whole sub models. If points in these plots did not differ significantly from the diagonal line, the normality assumption was considered as fulfilled. The model validation was realized by the comparison of $R^{2}$ and adjusted $R^{2}$ and $\mathrm{p}$-value analysis of the whole model.

The models of relations between customer satisfaction and loyalty and between customer loyalty and willingness to purchase additional products were validated by dividing the whole sample into two subsamples, creating alternative models for each of these subsamples and then comparing the alternative models one to another and to the original regression model as well. 


\section{Results and Discussion}

\subsection{Model of the Relation between Customer Satisfaction and Its Determinants}

The graphical test of linearity showed the fulfillment of this assumption, i.e. there were found clear linear relations between individual independent variables (individual approach to the client, financial needs recognition, customer acceptance of prices, quality and trust) and the dependent variable (customer satisfaction).

As for normality, the graphical test pointed to some deviations from the normal distribution, mainly for the variables quality and trust, what was confirmed by the statistical test as well. The results of this test can be found in Tab. 1 .

The variables financial needs recognition and customer acceptance of prices does not follow the normal distribution in skewness, the variables quality and trust do not follow the normal distribution neither in skewness nor in kurtosis. Even though, we did not apply the data transformation in order to obtain the normal distribution as the effects of un normal distribution are negligible if the sample size is large enough (Hair, 2010).
The testing of homoscedasticity did not show any violation of this assumption for any independent variable.

Based on the correlation matrix presented in Tab. 2, the first independent variable to be included in the model was customer acceptance of prices. Other variables were then included according to their partial correlations and t-values. The view of these characteristics for the variables not included in the first phase can be found in Tab. 3 .

The analysis of t-values led to the conclusion that the variables individual approach (IA) and trust will not enter into the model as their t-values was only 0.496 and 1.096 respectively. The required t-value was 1.9462 (457 degrees of freedom, significance level 0.05 ).

The characteristics of the final model of customer satisfaction and its determinants are shown in Tab. 4. Based on the multiple regression analysis, the regression equation can be written as follows:

$$
\begin{aligned}
& C S=0.2098+0.275 \times C A P+ \\
& +0.1987 \times F N R+0.3335 \times Q,
\end{aligned}
$$

where: CS - customer satisfaction, CAP customer acceptance of prices, FNR - financial

\begin{tabular}{|c|c|c|c|c|}
\hline $\begin{array}{l}\text { Skewness, kurtosis and } \\
\text { of customer satisfaction }\end{array}$ & value of in & endent & les in th & \\
\hline Independent variable & Skewness & z-value & Kurtosis & z-value \\
\hline Individual approach (IA) & 0.108 & 0.921 & -0.629 & -1.697 \\
\hline Financial needs recognition (FNR) & -0.410 & -3.510 & 0.192 & 0.820 \\
\hline Customer acceptance of prices (CAP) & 0.230 & 1.968 & -0.489 & -1.852 \\
\hline Quality & -0.585 & -5.007 & 0.847 & 3.621 \\
\hline Trust & -0.429 & -3.688 & 0.584 & 2.499 \\
\hline
\end{tabular}
needs recognition, $Q-$ quality.

Source: own

Tab. 2: Correlation matrix of variables in the model of customer satisfaction

\begin{tabular}{l|r|r|r|r|r|r} 
& \multicolumn{1}{|c|}{ Satisfaction } & \multicolumn{1}{c|}{ IA } & \multicolumn{1}{c|}{ FNR } & \multicolumn{1}{c}{ CAP } & Quality & Trust \\
\hline Satisfaction & 1 & & & & & \\
\hline IA & 0.389816890 & 1 & & & & \\
\hline FNR & 0.611237944 & 0.59757744 & 1 & & & \\
\hline CAP & 0.639321509 & 0.26400066 & 0.54891516 & 1 & & \\
\hline Quality & 0.631976184 & 0.48924861 & 0.64112936 & 0.51499672 & 1 & \\
\hline Trust & 0.487771569 & 0.3825809 & 0.48143422 & 0.47430464 & 0.597596 & 1 \\
\hline
\end{tabular}


Tab. 3: Characteristics of the variables not included in the model in the first phase

\begin{tabular}{l|c|c}
\multicolumn{1}{c|}{ Independent variable } & Partial correlation & t-value \\
\hline Financial needs recognition & 0.4050 & 4.061 \\
\hline Trust & 0.2726 & 1.096 \\
\hline Individual approach & 0.2980 & 0.496 \\
\hline Quality & 0.4593 & 6.003 \\
\hline
\end{tabular}

Tab. 4: Characteristics of customer satisfaction regression model

Least squares multiple regression

\begin{tabular}{l|r}
\hline $\mathrm{R}^{2}$ & 0.5577 \\
\hline Adjusted $\mathrm{R}^{2}$ & 0.5546 \\
\hline Multiple correlation coefficient & 0.7468 \\
\hline Residual standard deviation & 0.4347 \\
\hline
\end{tabular}

\begin{tabular}{l|c|c|c|c|c|c}
\hline \multicolumn{7}{c}{ Regression equation } \\
\hline Independent variables & Coefficient & Std. Error & $r_{\text {partial }}$ & t-value & p-value & VIF \\
\hline (Constant) & 0.2098 & & & & & \\
\hline Customer acceptance of prices & 0.2750 & 0.02987 & 0.4036 & 9.206 & $<0.0001$ & 1.530 \\
\hline Financial needs recognition & 0.1987 & 0.04071 & 0.2278 & 4.880 & $<0.0001$ & 1.909 \\
\hline Quality & 0.3335 & 0.04666 & 0.3242 & 7.148 & $<0.0001$ & 1.815 \\
\hline \multicolumn{7}{|c|}{ Analysis of variance } \\
F-ratio
\end{tabular}

Even though the first variable to enter into the model was customer acceptance of prices, quality showed the most significant influence on customer satisfaction in the final model. There was also found out that the effect of multicollinearity was not substantial as the highest Variance Inflation Factor (VIF) reached the level of 1.909 (Hair, 2010). A graphical test of the whole model on the assumptions of linearity, homoscedasticity and independence of residuals showed that all these assumptions were met. The normality assumption was met as well, judging from the normal probability plot constructed for the whole sub model.

The model validation comparing $\mathrm{R}^{2}$ and adjusted $R^{2}$ eliminated the possibility of sample over fitting as the difference between these two characteristics was minimal ( 0.5577 vs. 0.5546$)$. The created sub model can explain $55.57 \%$ of the variability of customer satisfaction. P-value of the whole sub model is $<0.0001$ which points to the statistical significance of the sub model (the required $p$-value is $<0.05$ ).

Our findings are in line with various papers preferring the SERVQUAL model (llyas et al., 2013; Arbore \& Busacca, 2009; Khan \& Rizwan, 2014). In these papers, as well as in our research, the product quality proved to have a significant impact on customer satisfaction. On the other hand, our model excluded the variable trust what is contradictory to the conclusions of Khan \& Rizwan (2014) 
and Aldas-Manzano (2011). Both of these studies confirmed the significance of trust as a customer satisfaction determinant.

\subsection{Model of the Relation between Customer Satisfaction and Loyalty}

Tests of linearity and homoscedasticity showed these assumptions were met for this model. The last assumption of linear regression, normality of data, was tested by normal probability plot first. Some violations were possible to observe thus a statistical test of normality was conducted as well. The results of such a test are presented in Tab. 5 and confirm that the independent variable (satisfaction) does not follow normal distribution. Box-Cox transformation to normality was then carried out yet without a deserved effect of normality of data $(\lambda=0.61)$. Considering the sample size which was large enough to ensure the abnormality of data would not have substantial impact on the data interpretation, it was decided to operate with the original, untransformed data.

The characteristics of the regression model of relation between customer satisfaction and loyalty are shown in Tab. 6. The model has the coefficient of determination $R^{2}$ at 0.5256 meaning it explains $52.56 \%$ of variance of the dependent variable. The F-ratio analysis led to the conclusion that the model can be considered as statistically significant ( $p$-value $<0.0001$ ). The regression equation can be written as follows:

$$
C L=0.01163+0.9191 \times C S,
$$

where: $C L$ - customer loyalty, CS - customer satisfaction.

Calculated t-value proved the significance of customer satisfaction as a determinant of customer loyalty. The actual t-value was 22.0021 , substantially exceeding the table criteria of 1.9462 (457 degrees of freedom, $\alpha=$ 0.05). The null hypothesis stating the statistical insignificance of the factor can thus be rejected. On the opposite, the constant of the equation was found to be statistically insignificant as its $\mathrm{p}$-value was at the level of 0.7182 , being above the critical value of 0.05 .

The next step was to test the model of the relation between customer satisfaction and loyalty as a whole to meet the assumptions of linear regression. Based on the graph of

\section{Tab. 5: Statistical test of normality of independent variable - customer satisfaction}

\begin{tabular}{c|c|c|c}
\hline Skewness & z-value & Kurtosis & z-value \\
\hline-0.28752 & -2.45935 & 0.691722 & 2.958411 \\
\hline
\end{tabular}

\section{Tab. 6: Characteristics of the regression model of customer loyalty (own research)}

\begin{tabular}{|c|c|c|c|c|c|}
\hline \multicolumn{6}{|c|}{ Least squares regression } \\
\hline \multicolumn{4}{|c|}{ Coefficient of determination $\mathrm{R}^{2}$} & \multicolumn{2}{|c|}{0.5256} \\
\hline \multicolumn{4}{|c|}{ Residual standard deviation } & \multicolumn{2}{|c|}{0.5694} \\
\hline \multicolumn{6}{|c|}{ Regression equation } \\
\hline Parameter & Coefficient & Std. Error & $95 \%$ confidence interval & t-value & $p$-value \\
\hline Intercept & 0.01163 & 0.03220 & -0.05166 to 0.07491 & 0.3610 & 0.7182 \\
\hline Slope & 0.9191 & 0.04177 & 0.8370 to 1.0012 & 22.0021 & $<0.0001$ \\
\hline \multicolumn{6}{|c|}{ Analysis of variance } \\
\hline \multicolumn{4}{|l|}{ F-ratio } & \multicolumn{2}{|c|}{484.0934} \\
\hline \multicolumn{4}{|c|}{ Significance level } & \multicolumn{2}{|c|}{$p<0.0001$} \\
\hline
\end{tabular}


standardized residuals of loyalty predicted by the created model, meeting the assumptions of linearity, homoscedasticity and independence of residuals was confirmed. Normal probability plot subsequently showed the assumption of normal distribution for the whole model was met as well.

The model of customer loyalty was validated by dividing the sample into two subsamples, creating separate regression models for these subsamples and comparing them both one to another and to the original model. The regression models of the subsamples are presented in Tab. 7.

As it can be observed from the table, newly created models differ only marginally, both from each other and from the original model. $R^{2}$ for the first subsample (Sample A) was 0.498 , for the second one (Sample B) it reached the level of 0.551 . The original model's explanatory power is thus in between these two models $\left(R^{2}=0.5256\right)$. The same holds true for the standard error and the slope (coefficient) of independent variable. The regression coefficient of independent variable was 0.882 for the sample A and 0.952 for the sample B. Both of these values fall into the $95 \%$ confidence interval of the original model coefficient. All the above mentioned facts enable to generalize the results of the original model to the whole population.

Our conclusion that customer satisfaction has a significant impact on customer loyalty is in line with the conclusions of Munari et al. (2013), Khan \& Fasih (2014), Khan \& Rizwan (2014). At the same time, it is contradictory to the study of Murugiah \& Akgam (2015) which found that the relation between customer satisfaction and loyalty works reversely, i.e. customer satisfaction depends on customer loyalty.

\subsection{Model of the Relation between Customer Loyalty and Additional Purchases Potential}

As for testing the independent variable to meet linear regression assumptions, linear trend was easy to observe from the scatter plot meaning the assumption was met. The homoscedasticity assumption was also met as standard residuals were distributed homogeneously throughout the standard residual plot. The assumption of normality was firstly tested graphically, showing some violations mainly in the area of the minimum and the maximum of the independent variable. As a result, independent variable was then tested statistically, namely

\section{Tab. 7: Regression models of separate subsamples validating the original model of customer loyalty}

\begin{tabular}{|c|c|c|c|c|c|c|}
\hline $\begin{array}{l}\text { Regression } \\
\text { Statistics }\end{array}$ & Sample A & Sample B & & & & \\
\hline Multiple R & 0.705603 & 0.742374 & & & & \\
\hline $\mathrm{R}^{2}$ & 0.497875 & 0.551119 & & & & \\
\hline Adjusted $\mathrm{R}^{2}$ & 0.495561 & 0.549060 & & & & \\
\hline Standard Error & 0.573826 & 0.565766 & & & & \\
\hline \multicolumn{7}{|c|}{ ANOVA Sample A } \\
\hline & Coefficients & $\begin{array}{l}\text { Standard } \\
\text { Error }\end{array}$ & t Stat & $p$-value & Lower 95\% & Upper 95\% \\
\hline Intercept & 0.002041 & 0.045297 & 0.045048 & 0.964111 & -0.08724 & 0.091319 \\
\hline Satisfaction & 0.882344 & 0.060153 & 14.66844 & $2.63 E-34$ & 0.763786 & 1.000902 \\
\hline \multicolumn{7}{|c|}{ ANOVA Sample B } \\
\hline & Coefficients & $\begin{array}{l}\text { Standard } \\
\text { Error }\end{array}$ & t Stat & p-value & Lower 95\% & Upper 95\% \\
\hline Intercept & 0.021105 & 0.045856 & 0.460252 & 0.645794 & -0.06927 & 0.111483 \\
\hline Satisfaction & 0.951759 & 0.058176 & 16.36009 & $8.76 \mathrm{E}-40$ & 0.837101 & 1.066418 \\
\hline
\end{tabular}


Tab. 8: Statistical test of normality of independent variable - customer loyalty

\begin{tabular}{c|c|c|c}
\hline Skewness & z-value & Kurtosis & z-value \\
\hline-0.50816 & -4.3467 & -0.14769 & -0.63164 \\
\hline
\end{tabular}

Source: own

calculating its skewness, kurtosis and z-values for these characteristics. The calculated values are shown in Tab. 8. The skewness characteristics exceeded the critical value meaning the independent variable showed abnormal distribution in this characteristic. Box-Cox transformation with the exponent $\lambda=1.15$ did not lead to normal distribution either. Subsequently, the model was created with the original, abnormal data taking into account the sufficient sample size.

The regression model of relation between customer loyalty and additional purchases potential can be found in Table 9. Considering that $p$-value of the whole model was at lower level than the significance level (0.05), the model is said to be statistically significant. The regression equation can be written as follows:

$$
A P P=-0.05667+0.5848 \times C L,
$$

where: $A P P$ - additional purchases potential, $C L$ - customer loyalty.

The $p$-value analysis showed the constant was not statistically significant $(0.0513)$ 0.05). On the opposite, there was found a statistically substantial relation between customer loyalty and additional products potential ( $p$-value < 0.0001). This conclusion was confirmed by the calculated t-value for the independent variable. Being it 18.4201 , it significantly exceeds the critical value of 1.9462 (457 degrees of freedom, $\alpha=0.05$ ).

Finally, the model of customer potential of purchasing additional products was tested to meet the linear regression assumptions as a whole. The first three of them were tested by a scatter plot. Judging from a clear linear trend to be observed in the scatter plot, the linearity assumption was met. Stochastic behavior of standard residuals together with their homogeneous distribution throughout the whole graph led to the conclusion about homoscedasticity of the whole model. The attempt to create a prediction of residuals was not successful what points out to the independence of residuals - the third assumption was thus met as well. The normality assumption was tested by a normal probability plot. It was not possible to see any strong deviations from the diagonal line concluding that the whole model follows the normal distribution.

Also the model of the relation between customer loyalty and additional purchases potential was validated by dividing the whole sample into two subsamples, creating separate

\section{Tab. 9: Characteristics of the regression model of customers' additional purchases potential}

\begin{tabular}{|c|c|c|c|c|c|}
\hline \multicolumn{6}{|c|}{ Least squares regression } \\
\hline \multicolumn{5}{|c|}{ Coefficient of determination $\mathrm{R}^{2}$} & 0.4371 \\
\hline \multicolumn{5}{|c|}{ Residual standard deviation } & 0.5487 \\
\hline \multicolumn{6}{|c|}{ Regression equation } \\
\hline Parameter & Coefficient & Std. Error & 95\% confidence interval & t-value & $p$-value \\
\hline Intercept & -0.05667 & 0.02899 & -0.1136 to 0.0003116 & -1.9547 & 0.0513 \\
\hline Slope & 0.5848 & 0.03175 & 0.5224 to 0.6472 & 18.4201 & $<0.0001$ \\
\hline \multicolumn{6}{|c|}{ Analysis of variance } \\
\hline \multicolumn{5}{|l|}{ F-ratio } & 339.3004 \\
\hline \multicolumn{5}{|c|}{ Significance level } & $p<0.0001$ \\
\hline
\end{tabular}


Tab. 10: Regression models of subsamples validating the original model of customer potential of additional purchases

\begin{tabular}{|c|c|c|c|c|c|c|}
\hline Regression Statistics & Sample A & Sample B & & & & \\
\hline Multiple R & 0.648366 & 0.670267 & & & & \\
\hline $\mathrm{R}^{2}$ & 0.420379 & 0.449258 & & & & \\
\hline Adjusted $\mathrm{R}^{2}$ & 0.417708 & 0.446732 & & & & \\
\hline Standard Error & 0.528713 & 0.568463 & & & & \\
\hline \multicolumn{7}{|c|}{ ANOVA Sample A } \\
\hline & Coefficients & $\begin{array}{l}\text { Standard } \\
\text { Error }\end{array}$ & t Stat & $p$-value & Lower 95\% & $\begin{array}{l}\text { Upper } \\
95 \%\end{array}$ \\
\hline Intercept & -0.07149 & 0.038871 & -1.83912 & 0.067264 & -0.148100 & 0.005124 \\
\hline Loyalty & 0.556025 & 0.044322 & 12.54521 & 1.66E-27 & 0.468669 & 0.643381 \\
\hline \multicolumn{7}{|c|}{ ANOVA Sample B } \\
\hline & Coefficients & $\begin{array}{l}\text { Standard } \\
\text { Error }\end{array}$ & t Stat & $p$-value & Lower 95\% & $\begin{array}{l}\text { Upper } \\
95 \%\end{array}$ \\
\hline Intercept & -0.042140 & 0.043206 & -0.97525 & 0.330515 & -0.12729 & 0.043018 \\
\hline Loyalty & 0.608001 & 0.045593 & 13.33528 & 4.64E-30 & 0.51814 & 0.697861 \\
\hline
\end{tabular}

Source: own

regression models for these subsamples and comparing them both to one another and to the original model. The characteristics of the newly created models are to be found in Tab. 10.

All the characteristics of the newly created models (multiple $\mathrm{R}, \mathrm{R}^{2}$, adjusted $\mathrm{R}^{2}$, standard error) fall into the $95 \%$ confidence interval of the original model what confirms there were only marginal differences comparing these models one to another and to the original model as well. The similarity of the models leads to the conclusion that the original model is not characteristic only for a small specific sample but it is generalizable to the whole population.

The confirmed relation between customers' loyalty and their potential of additional purchases is in accord with the studies of Khan \& Fasih (2014) and Gee et al. (2008). Liang et al. (2009), Smith \& Wright (2004) or Al-Wugayan \& Pleshko (2010) also state that the direct consequence of customer loyalty is higher profitability of a commercial bank. However, Kumar \& Shah (2004) argue that a bank has to build customer loyalty step by step in order to obtain higher profits. The first step is to develop behavioral loyalty; the second one is attitudinal loyalty and only the third phase means connecting the bank's profitability with customer loyalty. The authors thus declare there does not have to be a direct relation between customer loyalty and higher bank's profitability in every case.

\subsection{The Final Model of Customer Satisfaction - Customer Loyalty - Additional Purchases Potential}

The final model is depicted in Fig. 2. As it was seen above, independent variables individual approach and trust did not meet the criteria to enter the model of customer satisfaction. Consequently, these variables are not included in the final model what is the main difference between the proposed and the final model. As for trust, the reason why it did not fit the criteria could be the fact that it is "the basic factor" (Munari et al., 2013). Czech bank clients' trust is generally at a high level: according to the research of Ernst \& Young, 96\% of Czech bank customers trust their bank (Ernst \& Young, 2014); our own research showed $88 \%$ level of trust. The fact that clients trust their bank is thus given: although customers' distrust leads to their dissatisfaction, this flow does not work vice-versa. If clients believe their bank is a solid partner, it does not influence their satisfaction. Regarding individual approach, this variable was not included in the model because of its relatively high level of correlation with financial needs acceptance $(0.5976)$. 


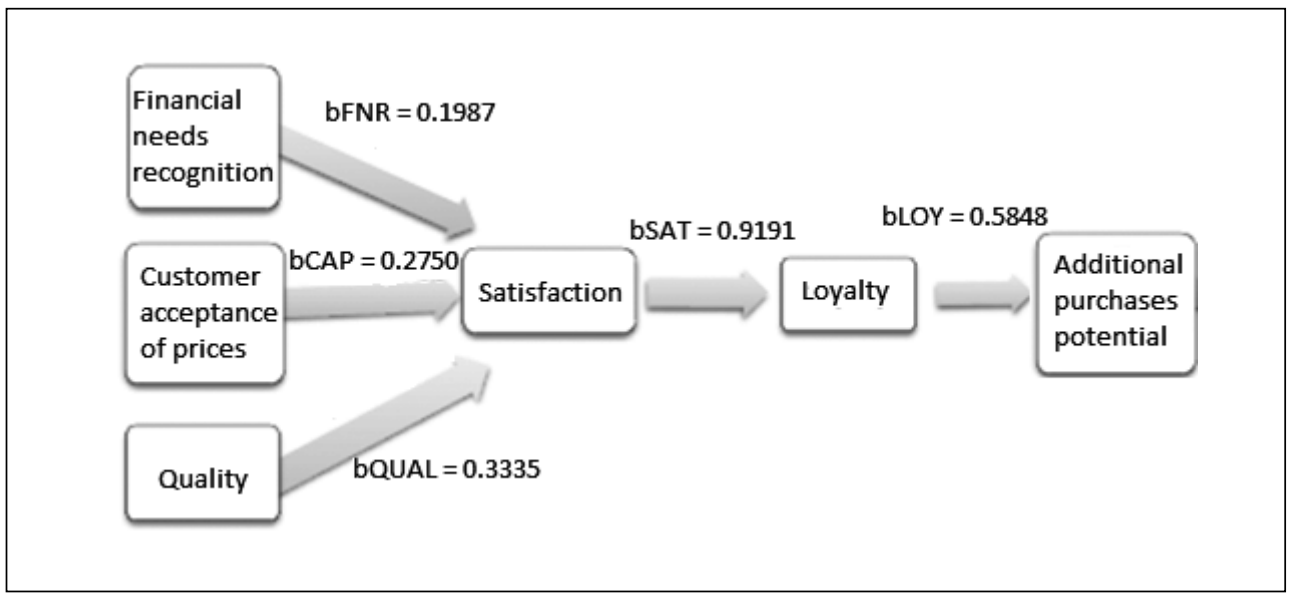

Source: own

\subsection{Managerial Consequences: a Practical Example}

In this chapter there is presented an example of how a Czech commercial bank's financial performance can improve if it increases the number of loyal clients. The example is based on the information that was obtained during our research and on publicly available data about the banking sector in the Czech Republic.

Assignment: How can the Czech commercial bank's income change if it increases the number of its loyal customers by 10,000 ?

Equation to calculate the result: an additional revenues caused by an increased number of loyal customers is defined as a function of sales a bank can potentially obtain from selling products to these customers. The equation can be mathematically written as follows:

$$
\begin{aligned}
& R_{A}=f\left(X_{1}, X_{2}, X_{3} \ldots \ldots X_{n}\right)= \\
& =\Delta L C \times b_{L O Y} \times\left(v_{1} \times i m_{D}+v 2 \times i r M+\right. \\
& +v 3 \times R 3+\ldots \ldots+v n \times R n)
\end{aligned}
$$

where: $\mathrm{R}_{\mathrm{A}}$ - additional annual revenues of a commercial bank, $X_{1}$ - deposit products, $X_{2}-$ mortgage loans, $X_{3-n}$ - other banking products, $\Delta L C$ - change in number of loyal customers, $b_{\text {Lor }}$ - regression coefficient of the relation between customer loyalty and additional purchases potential (see Fig. 2), $v_{1} \ldots v_{n}$ - volume of sold product $1 \ldots \mathrm{n}, \mathrm{im}_{\mathrm{D}}$ - average interest margin of time deposits, $\mathrm{ir}_{M}$ - average interest rate of mortgage loans, $r_{3-n}$ - average annual revenue per unit of a certain product.

Solution: Average characteristics for the Czech banking sector were used to calculate the solution. We abstracted from other products $\left(x_{3-n}\right)$ as their features are too complex to summarize them into average indicators. Moreover, our own research has shown only $30.3 \%$ of clients are interested in investing on financial markets with their bank and to purchase others banking products (significantly lower level than the interest in deposit products and mortgage loans). The parameters calculated in CZK according to the data of the Czech National Bank (2015) and Fincentrum (2015) were converted to EUR by an exchange rate 1 EUR $=28 \mathrm{CZK}$. The parameters necessary to obtain the results were found out to be as follows: average interest margin of time deposits $=2.689 \%$ p.a., average deposit balance $=8,216.498$ EUR, average mortgage loan remaining balance $=59,621.393$ EUR, average interest rate of mortgage loans = $2.370 \%$ p.a.

Consequently, the example can be solved as follows:

$$
\begin{aligned}
& R_{A}=10,000 \times 0.5848 \times(0.02689 \times \\
& \times 8,216.498+0.02370 \times 59,621.393)= \\
& =9,555,456.56 \text { EUR }
\end{aligned}
$$


Result: If a Czech commercial bank increases the number of loyal customers by 10,000 , its additional income can grow by almost 9.6 million EUR.

To better illustrate the example, in case of the biggest Czech bank 10,000 clients represent $0.2 \%$ of the total number of clients. At the same time, increasing its revenues by 9.6 million EUR means a growth of $1.8 \%$. If this bank was able to boost the number of its loyal customers by 100,000 ( $2 \%$ of the total), it could improve its revenues by 96 million EUR what represents revenues growth of solid $18 \%$.

Our research showed the current value of Cross Selling Index (defined as a number of products sold to one client) in the Czech banking sector is only 2.21. There was also found out that the total customer satisfaction is at the level of $66 \%$. In conclusion, there is a large space for banks' management to both improve the current levels of loyal customers and then increase the number of products sold to one client.

\section{Conclusion}

In the current banking sector, characterized by an increasing competition, efficient management of selling additional products and services to existing satisfied customers represents a significant opportunity to improve the financial performance of a commercial bank.

The aim of this article was to create a model of customer satisfaction in the Czech banking sector and to quantify the intensity of relations among customer satisfaction, customer loyalty and financial performance of a commercial bank. It was found out that a customer satisfaction is dependent mainly on the quality of bank products, customers' financial needs recognition by a bank and customer acceptance of prices. The other two variables originally proposed in the model (individual approach and trust) have not proved to have a significant effect.

The research confirmed there is a relation between customer satisfaction and customer loyalty and between customer loyalty and additional purchases potential of a client. The biggest potential of additional sales was found in the segment of deposit products and mortgage loans: $60.8 \%$ of loyal clients declared that if they saved some money, they would deposit them into their bank and $49 \%$ of loyal clients would address their bank in case of interest in a mortgage loan. On the other hand, only $30.3 \%$ of respondents stated they would realize financial markets investments with their bank in case of interest.

The practical example confirmed the economic significance of customer satisfaction for commercial banks. If a Czech bank is able to increase the number of its satisfied clients by 10,000 , it can obtain additional annual income of nearly 9.6 million EUR. For the largest Czech bank it represents an income growth of $1.8 \%$. Thus, if bank management wants to ensure better financial performance of a bank, customer satisfaction management has to become one of its priorities.

Our study, not unlike others, has its limitations, such as number of respondents in an own research, territory of its conduct, abstraction from several factors (e.g. other products in the practical examples). Nevertheless, we assume our paper can become an inspiration for bank management as well as for further research activities.

Authors are thankful to the Internal Grant Agency of FaME TBU No. 005/IGA/ FaME/2014: Optimization of parameters of the financial performance of the commercial bank, for financial support to carry out this research.

\section{References}

Al-Wugayan, A., \& Plesko, L.P. (2010). A Study of Satisfaction, Loyalty, and Market Share in Kuwait Banks. Proceedings of the Academy for Studies in International Business, 10(1), 2-7. doi:10.1108/IJBM-11-2012-0114.

Aldas-Manzano, J. (2011). Internet Banking Loyalty: Evaluating the Role of Trust, Satisfaction, Perceived Risk and Frequency of Use. Service Industries Journal, 31(7), 11651190. doi:10.1080/02642060903433997.

Arbore, A., \& Busacca, B. (2009). Customer Satisfaction and Dissatisfaction in Retail Banking: Exploring the Asymmetric Impact of Attribute Performances. Journal of Retailing and Consumer Services, 16(4), 271-280. doi:0.1016/j.jretconser.2009.02.002.

Belás, J., Chocholáková, A., \& Gabčová., L. (2015). Satisfaction and loyalty of banking customers: a gender approach. Economics and Sociology, 8(1), 176-188. doi:10.14254/2071789X.2015/8-1/14.

Belás, J., Cipovová, E., \& Demjan, V. (2014). Current trends in area of satisfaction of banks' 
clients in the Czech Republic and Slovakia. Transformation in Business \& Economics, 13.3(33), 219-234.

Belás, J., \& Gabčová, L. (2014). Reasons for Satisfaction and Dissatisfaction of Bank Customers: Study from Slovakia and the Czech Republic. International Journal of Entrepreneurial Knowledge, 2(1), 4-13. doi:10.15759/ijek/2014/v2i1/53759.

Bena, I. (2010). Evaluating Customer Satisfaction in Banking Services. Management \& Marketing, 5(2), 143-150.

Bernhardt, K.L., et al. (2000). A Longitudinal Analysis of Satisfaction and Profitability. Journal of Business Research, 47(2), 161-171. doi:10.1016/S0148-2963(98)00042-3.

Bilan, Y. (2013). Sustainable development of a company: Building of new level relationship with the consumers of XXI. Century. Amfiteatru Economic, 15(7), 687-701.

Burianová, L., Paulík, J. (2014). Corporate Social Responsibility in Commercial Banking. A Case Study from the Czech Republic. Journal of Competitiveness, 6(1), 50-70. doi:10.7441/ joc.2014.01.04.

Clerfeuille, F., et al. (2008). Evaluation of Consumer Satisfaction Using the Tetra-class Model. Research in Social and Administrative Pharmacy, 4(3), 258-271. doi:10.1016/j. sapharm.2007.06.020.

Cohon, C. (2007). Customer Loyalty. Sales and Marketing Management, 159(5), 46-59.

Czech National Bank. (2015). Arad: system časových řad. Retrieved July 11, 2015, from http://www.cnb.cz/cnb/STAT. ARADY_PKG.PARAMETRY_SESTAVY?p_ sestuid $=33051 \& p$ _strid=BAB\&p_lang $=C S$.

Ernst \& Young. (2014). Více než polovina českých klientů bank si důvěru v banku spojuje s otázkou poplatků. Retrieved March 19, 2015, from http://www.ey.com/CZ/cs/Newsroom/ News-releases/2014_Vice-nez-polovinaceskych-klientu-bank-si-duveru-v-bankuspojuje-s-otazkou-poplatku.

Fatima, J.K., Razzaque, M.A. (2014). Service quality and satisfaction in the banking sector. International Journal of Quality \& Reliability Management, 31(4), 367-379.

Ferreira, F.A.F., Jalali, M.S., Kavaliauskiene, I.M., \& Viana, B.A.C.P. (2015). A metacognitive decision making based-framework for bank customer loyalty measurement and management. Technological and Economic Development of Economy, 21(2), 280-300. doi:10.3846/20294913.2014.981764

Fincentrum. (2015). Rekordní rok byl završen královsky. Retrieved April 8, 2015, from http://www.hypoindex.cz/fincentrum-prosinec2014-rekordni-rok-byl-zavrsen-kralovsky/.

Fraering, M., \& Minor, M.S. (2013). Beyond Loyalty: Customer Satisfaction, Loyalty, and Fortitude. The Journal of Services Marketing, 27(4), 334-344. doi:10.1108/08876041311330807.

Gee, R., et al. (2008). Understanding and Profitably Managing Customer Loyalty. Marketing Intelligence and Planning, 26(4), 359-374. doi:10.1108/02634500810879278.

Gursoy, D., \& Swanger, N. (2007). Performance - enhancing Internal Strategic Factors: Impacts on Financial Success. International Journal of Hospitality Management, 26(1), 213-227. doi:10.1016/j. ijhm.2006.01.004.

Hair, J.F. (2010). Multivariate data analysis. Upper Saddle River: Prentice-Hall.

Hernaus, A.I., Stojanovic, A. (2015). Determinants of bank social responsibility: A case study of Croatia. E\&M Ekonomie a Management, 18(2), 117-134. doi:10.15240/ tul/001/2015-2-009.

Chavan, J., \& Ahmad, F. (2013). Factors Affecting On Customer Satisfaction in Retail Banking: An Empirical Study. International Journal of Business and Management Invention, 2(1), 55-62.

Chi, C.G., \& Gursoy, D. (2009). Employee Satisfaction, Customer Satisfaction, and Financial Performance: An Empirical Examination. International Journal of Hospitality Management, 28(2), 245-253. doi:10.1016/j. ijhm.2008.08.003.

Ilyas, A., et al. (2013). Assessing the Service Quality of Bank Using SERVQUAL Model. Interdisciplinary Journal of Contemporary Research In Business, 4(11), 390-400.

Kamakura, W.A., et al. (2002). Assessing the Service - Profit Chain. Marketing Science, 21(3), 294-317. doi:10.1287/mksc.21.3.294.140.

Keisidou, E., Lazaros, S., Maditions, D.I., \& Thalassinos, E.I. (2013). Customer satisfaction, loyalty and financial performance: a holistic approach of the Greek banking sector. International Journal of Bank Marketing, 31(4), 259-288. doi:10.1108/IJBM-11-2012-0114.

Khan, M.M., \& Fasih, M. (2014). Impact of Service Quality on Customer Satisfaction and Customer Loyalty: Evidence from Banking 
Sector of Pakistan. Journal of Commerce and Social Sciences, 8(2), 331-354.

Khan, B., \& Rizwan, M. (2014). Factors Contributing to Customer Loyalty in Commercial Banking. International Journal of Accounting and Financial Reporting, 4(2), 413-436. doi:10.5296/ijafr.v4i2.6537.

Kheng, L.L., et al. (2010). The Impact of Service Quality on Customer Loyalty: A study of Banks in Penang, Malaysia. International Journal of Marketing Studies, 2(2), 57-66. doi:10.5539/ijms.v2n2p57.

Kumar, V., Shah, D. (2004). Building and Sustaining Profitable Customer Loyalty for the 21st Century. Journal of Retailing, 80(4), 317330. doi:10.1016/j.jretai.2004.10.007.

Ladhari, R., Souiden, N., \& Ladhari, I. (2011). Determinants of loyalty and recommendation: the role of perceived service quality, emotional satisfaction and image. Journal of Financial Services Marketing, 16(2), 111-124. doi:10.1057/fsm.2011.10.

Lenka, U., Saur, D., \& Mohapatra, P.K.J. (2009). Service quality, customer satisfaction and customer loyalty in Indian commercial banks. The Journal of Entrepreneurship, 18(1), 47-64. doi:10.1177/097135570801800103.

Liang, C.J., et al. (2009). The Influence of Customer Perceptions on Financial Performance in Financial Services. International Journal of Bank Marketing, 27(2), 129-149. doi:10.1108/02652320910935616.

Matzler, K., Renzl, B., \& Faullant, R. (2007). Dimensions of Price Satisfaction: A Replication and Extension. International Journal of Bank Marketing, 25(6), 394-405. doi:10.1108/02652320710820345.

Munari, L., lelasi, F., Bajetta, L. (2013). Customer Satisfaction Management in Italian Banks. Qualitative Research in Financial Markets, 5(2), 139-160. doi:10.1108/QRFM-112011-0028.

Murugiah, L., \& Akgam, H.A. (2015). Study of Customer Satisfaction in the Banking Sector in Libya. Journal of Economics, Business and Management, 3(7), 674-677. doi:10.7763/ JOEBM.2015.V3.264.

Oliver, R.L. (2010). Satisfaction: a behavioral perspective on the consumer. Armonk, N.Y.: M.E. Sharpe.

Roig, J.C.F., Garcia, J.S., \& Tena, M.A.M. (2009). Perceived value and customer loyalty in financial services. The Service Industries Journal, 29(6), 775-789. doi:10.1080/02642060902749286.

Shiv, B., \& Huber, J. (2000). The Impact of Anticipating Satisfaction on Consumer Choice. Journal of Consumer Research, 27(2), 202216.

Smith, R.E., \& Wright, W.F. (2004). Determinants of Customer Loyalty and Financial Performance. Journal of Management Accounting Research, 16(1), 183-205. doi:10.2308/jmar.2004.16.1.183.

Wang, J., \& Wallendorf, M. (2006). Materialism, Status Signaling, and Product Satisfaction. Academy of Marketing Science Journal, 34(4), 494-505. doi:0.1177/0092070306289291.

Zeithaml, V. (2000). Service Quality, Profitability, and the Economic Worth of Customers: What We Know and What We Need to Learn. Journal of the Academy of Marketing Science, 28(1), 67-85. doi:10.1177/0092070300281007.

prof. Ing. Jaroslav Belás, Ph.D. Thomas Bata University Faculty of Management and Economics Department of Enterprise Economics belas111@gmail.com

Ing. Lenka Gabčová

Thomas Bata University Faculty of Management and Economics Department of Enterprise Economics I.gabcova@gmail.com 


\section{Abstract}

\section{THE RELATIONSHIP AMONG CUSTOMER SATISFACTION, LOYALTY AND FINANCIAL PERFORMANCE OF COMMERCIAL BANKS}

\section{Jaroslav Belás, Lenka Gabčová}

In the current banking sector, characterized by an increasing competition, efficient management of selling additional products and services to existing satisfied customers represents a significant opportunity to improve the financial performance of a commercial bank. To sum up, the conclusion of the up to date literature is an idea that customer satisfaction leads to customer loyalty and loyalty leads to willingness to purchase additional products. However, there are practically no papers quantifying the influence of loyalty on additional products purchases. The aim of this paper is to create a model among customer satisfaction, loyalty and financial performance of commercial banks in the Czech Republic. It is based on our original research realized as a survey with a total of 459 respondents that have been reached. The created model has proven that product quality, recognition of customers' financial needs and acceptance of prices by a customer have an impact on customer satisfaction, which then influences customer loyalty and this in return influences additional purchases potential of a customer. The regression model of relation between customer satisfaction and loyalty of bank customer has this form: $C L=0.01163+0.9191 \times C S$, where: CL - customer loyalty, CS customer satisfaction. The regression model of relation between customer loyalty and additional purchases: $A P P=-0.05667+0.5848 \times C L$, where: $A P P$ - additional purchases potential, $C L-$ customer loyalty. At the end, the paper is dedicated to a model example showing that if a commercial bank is able to increase the number of satisfied customers by 10,000, it can obtain additional yearly income of EUR 9.6 million.

Key Words: Commercial banks, customer satisfaction, customer satisfaction determinants, customer loyalty, cross-selling, banks' additional income.

JEL Classification: G21.

DOI: 10.15240/tul/001/2016-1-010 